\title{
Challenges and Opportunities of Mass Vaccination Centers in COVID-19 Times: A Rapid Review of Literature
}

\author{
Vincenza Gianfredi ${ }^{1,2, *(1)}$, Flavia Pennisi ${ }^{1}$, Alessandra Lume ${ }^{1}$, Giovanni Emanuele Ricciardi ${ }^{1}$, \\ Massimo Minerva ${ }^{1}$, Matteo Riccò ${ }^{3}$ (i) , Anna Odone ${ }^{4}$ and Carlo Signorelli ${ }^{1}$ (i) \\ 1 School of Medicine, Vita-Salute San Raffaele University, 20132 Milan, Italy; pennisi.flavia@hsr.it (F.P.); \\ lume.alessandra@hsr.it (A.L.); ricciardi.giovanni@hsr.it (G.E.R.); minerva.massimo@hsr.it (M.M.); \\ signorelli.carlo@hsr.it (C.S.) \\ 2 Care and Public Health Research Institute (CAPHRI), Maastricht University, \\ 6211 Maastricht, The Netherlands \\ 3 AUSL-IRCCS di Reggio Emilia, Servizio di Prevenzione e Sicurezza Negli Ambienti di Lavoro (SPSAL), \\ Via Amendola n.2, 42122 Reggio Emilia, Italy; matteo.ricco@ausl.re.it \\ 4 Department of Public Health, Experimental and Forensic Medicine, University of Pavia, 27100 Pavia, Italy; \\ anna.odone@unipr.it \\ * Correspondence: gianfredi.vincenza@hsr.it
}

\section{check for} updates

Citation: Gianfredi, V.; Pennisi, F.; Lume, A.; Ricciardi, G.E.; Minerva, M.; Riccò, M.; Odone, A.; Signorelli, C. Challenges and Opportunities of Mass Vaccination Centers in COVID-19 Times: A Rapid Review of Literature. Vaccines 2021, 9, 574 . https://doi.org/10.3390/ vaccines 9060574

Academic Editors: Chiara de Waure, Aldo Rosano and Chiara Cadeddu

Received: 30 April 2021

Accepted: 28 May 2021

Published: 1 June 2021

Publisher's Note: MDPI stays neutral with regard to jurisdictional claims in published maps and institutional affiliations.

Copyright: (c) 2021 by the authors. Licensee MDPI, Basel, Switzerland. This article is an open access article distributed under the terms and conditions of the Creative Commons Attribution (CC BY) license (https:/ / creativecommons.org/licenses/by/ $4.0 /)$.

\begin{abstract}
A mass vaccination center is a location, normally used for nonhealthcare activities, set up for high-volume and high-speed vaccinations during infectious disease emergencies. The high contagiousness and mortality of COVID-19 and the complete lack of population immunity posed an extraordinary threat for global health. The aim of our research was to collect and review previous experiences on mass vaccination centers. On 4 April 2021, we developed a rapid review searching four electronic databases: PubMed/Medline, Scopus, EMBASE, Google Scholar and medRxiv. From a total of 2312 papers, 15 of them were included in the current review. Among them, only one article described a COVID-19 vaccination center; all of the others referred to other vaccinations, in particular influenza. The majority were conducted in the United States, and were simulations or single-day experiences to practice a mass vaccination after bioterrorist attacks. Indeed, all of them were published after September 11 attacks. Regarding staff, timing and performance, the data were highly heterogenous. Several studies used as a model the Center for Disease Control and Prevention guidelines. Results highlighted the differences around the definition, layout and management of a mass vaccination center, but some aspects can be considered as a core aspect. In light of this, we suggested a potential definition. The current review answers to the urgency of organizing a mass vaccination center during the COVID-19 pandemic, highlighting the most important organizational aspects that should be considered in the planning.
\end{abstract}

Keywords: health planning organizations; mass vaccination; vaccines; COVID-19; rapid review

\section{Introduction}

At the end of 2019, a novel highly infectious coronavirus, called SARS-CoV-2, emerged in the city of Wuhan (China), causing an outbreak of unknown viral pneumonia. Because of the high contagiousness and mortality, its global spread, the absence of effective drugs and the lack of population immunity, SARS-CoV-2 has rapidly become a global threat [1-4], culminating in the announcement of a pandemic by the World Health Organization (WHO) on 11 March 2020 [5,6]. With preventive measures limited to nonpharmaceutical interventions (NPI) (i.e., social distancing, extensive lockdown, etc.), of various efficacy and high social costs [7], the development of COVID-19 vaccines has become a globally shared priority, and research pathways were accelerated by pharmaceutical companies and research institutes through the strong support of central governments. Eventually, various types of vaccines have been developed, ranging from more conventional formulates based on 
SARS-CoV-2 subunits and/or proteins, live-attenuated and inactivated viruses, replicating and nonreplicating viral vectors, virus-like particles, and cell-based vaccines, to the more innovative mRNA/DNA based vaccines [8]. To date, two mRNA vaccine formulates, and two vaccines based on nonreplicating viral vectors have been licensed to emergency use in most high-income countries, making the vaccine available to vaccination campaigns.

Up to 27 April 2021, around 1 billion vaccine doses have been administered worldwide, equal to 13 doses for every 100 people [9]. Vaccination of the world base population is considered the most promising but also the most challenging approach because it requires the safe and effective delivery of millions of vaccine shots in the shortest period of time, while also avoiding health inequalities. The final aim of mass vaccination is to accelerate disease control through a rapid increase in vaccination coverage, achieving immunity levels essential to meet international goals for mortality reduction, and eventually allowing the ease of NPI [10]. To meet this goal, vaccines have to be made available all over the world, but this unprecedented production may fail in its goal without appropriate distribution and delivery of vaccines in targeted populations. In such a setting, mass vaccination centers (MVCs) are fundamental in minimizing the time required to vaccinate the highest number of people [10]. Due to the unique extent of this mass vaccination campaign, it is frequently held in nontraditional or temporary settings, such as in parking lots or large indoor spaces.

Even though mass vaccination campaigns have been a common element of communicable disease control programs (e.g., H1N1 influenza during the early 1970s and then during the winter season of 2008; smallpox; poliomyelitis, and typhoid fever) in both low-middle and high-income countries worldwide-and the Centers for Disease Control and Preventions (CDC) have issued specific guidelines on how to set up mass vaccination clinics for H1N1 campaigns [11] - no clear information has been previously collected and systematically appraised in medical literature. Moreover, the working definition is often inconsistent because it increasingly emerges while health authorities all around the world are implementing MCVs for COVID-19 vaccines. For example, during spring 2021, EuroDisney Paris was temporarily converted into an MVC with a potential capability of 1000 doses / day, while the Health Ministry of Quebec in its guidelines specifically targeted 2500 doses/day, and during May 2021, MVCs from Italian high and medium-sized cities were able to immunize over 4000 subjects in a single day [12-15].

Moreover, it should be considered that MVCs for COVID-19 vaccination is the first mass vaccination of the modern era. In light of the above considerations, we performed a rapid review, of both scientific and grey literature sources, collecting and summarizing the past experiences of the MVCs in terms of buildings, staff, and time requirements, as well as for organizational programs needed. Moreover, based on retrieved information, we suggested a potential definition of a mass vaccination center. Lastly, our ultimate goal was to critically appraise the available evidence with the final aim of timely and efficiently informing policy makers in the organization of MVCs in different settings.

\section{Materials and Methods}

We developed a rapid review using the World Health Organization (WHO) guidelines, "Rapid reviews to strengthen health policy and systems: a practical guide" [16], and the Preferred Reporting Items for Systematic Reviews and Meta-Analyses (PRISMA) guidelines for reporting [17]. A standardized protocol identifying the research question, the search strategy, inclusion and exclusion criteria was developed and shared within the research team and fully approved before starting the review.

\subsection{Search Strategy and Data Sources}

Studies were retrieved by searching four electronic databases: PubMed/Medline, Scopus and Excerpta Medica database (EMBASE) to screen the scientific literature; Google Scholar and medRxiv to identify eligible documents from the grey literature. Additionally, we consulted professionals involved in the prompting of MVC and screened reference lists of the included articles in order to collect any other potentially relevant material. 
The literature search was carried out on the 4 April 2021 and it was developed based on a combination of keywords related to MVCs (and similar) and management (and similar), including both MeSH terms and free text words. The search strategy was firstly developed in PubMed/Medline and then adapted to the other databases. Keywords were logically combined with the Boolean operators "AND" and "OR". The full search strategy is available in Table S1.

\subsection{Inclusion and Exclusion Criteria}

Only original papers written in English and with full text available were included. Due to the aim of this review, we chose articles describing the characteristics of organization and implementation of MVCs, both in real world examples and computer simulations. In this review, we considered the following working definition for a mass vaccination center: points of massive dispensing of vaccines to a large share of the general population in response to an outbreak of a contagious disease. Moreover, any type of vaccine administered in mass vaccination campaigns was considered eligible. Indeed, we did not exclusively restrict our search to anti-COVID-19 vaccination. The reason behind this choice was mainly because, due to the novelty of the topic, we expected to find very few studies specifically referring to COVID-19. On the contrary, collected experiences regarding other vaccination campaigns could still provide useful and interesting suggestions. Moreover, in order to be considered eligible, articles should provide information regarding the organization, preparation and implementation of a mass vaccination center. In our research, no time filter was applied.

\subsection{Study Selection and Data Extraction}

Articles were first assessed based on title and abstract, and only eligible articles were evaluated in full by the researchers (A.L., G.E.R., M.M.). Data extraction was performed using a pre-piloted spreadsheet elaborated in Microsoft Excel ${ }^{\circledR}$ for Windows (Microsoft Corporation, Redmond, WA, USA). To standardize data extraction, a predefined spreadsheet was prepared by the team. Three authors performed data extraction (A.L., G.E.R., M.M.), revised and supervised by a fourth (senior) researcher (V.G.). Several qualitative and quantitative data were extracted from the original studies. Qualitative data recorded included the name of the first author, year of study, country, type of vaccine, preparation needs, layout. Quantitative data extracted included dimension of the mass vaccination center, presence of pharmacy room, restrooms, staffing, medical procedures, time and performance measures.

\section{Results}

\subsection{Literature Search}

A total of 2312 articles were initially retrieved by the literature search (Figure 1). After duplicates removal, 2283 articles were left for the title-abstract screening. Based on the title-abstract, 2237 articles were excluded, while the remaining 46 were screened by reading the full-text. In the second screening step, 31 articles were eliminated, and exclusion reasons are listed in Table S2 [18-48]. In brief, the full texts of four articles were not available despite many efforts to find them [18-21]. Nine articles did not provide details about the organization of an MVC [22-30], rather discussing challenges of mass anti-COVID-19 vaccination [23] or electronic systems used to monitor vaccine reactions and side effects [26]; or the time currently spent by primary care personnel in vaccinating [30]. At the end of the selection process, 15 articles were included in the current review [49-63], of which one article was identified screening the reference list [49]. 


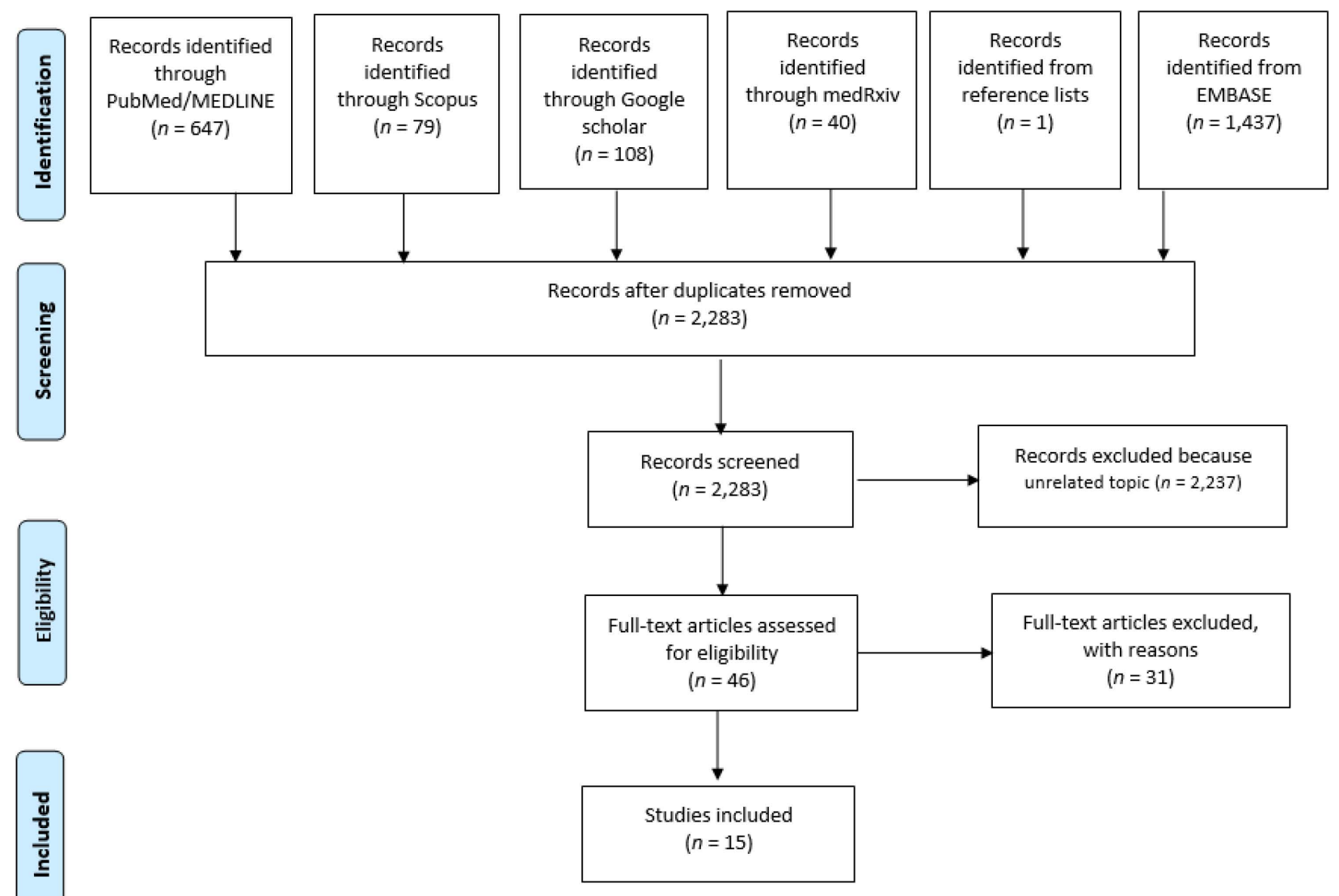

Figure 1. Flow diagram of the selection process.

\subsection{Characteristics of Included Studies}

Among the 15 retrieved articles, 14 were published on peer-reviewed scientific journals [49-61,63]; the remaining one was a newspaper article [62]. All but two articles [58,63] reported on experiences based in the USA, for a timeframe ranging from 2003 [50] to 2021 [62]. Interestingly, a significant share of the retrieved articles followed the great attention posed by US Institutions, after the September 11 attacks in 2001, to develop standard procedures in case of a bioterrorist attack or pandemic flu. Regarding the 13 USA-based articles, nine reported on seasonal influenza and H1N1 vaccination [51,53-57,59-61], two on smallpox vaccination $[49,50]$, and only one on the anti-SARS-CoV-2 vaccination campaign [62]. Among these 13 USA studies, two were not real-world assessments but rather computer simulations conducted by the same authors, assessing numerous scenarios and operating parameters in order to plan a mass vaccination center [51,52].

The remaining two articles reported on experiences from the People's Republic of China [58] and India [63], but neither was focused on anti-SARS-CoV-2 vaccination. In fact, the first one was based on a vaccination campaign to prevent typhoid fever and meningitis A [58], and the other one on a vaccination campaign with an oral cholera vaccine [63] (Table 1). 
Table 1. General characteristics of the included studies.

\begin{tabular}{|c|c|c|c|c|c|c|c|}
\hline Author & Year & Country & Vaccine & Preparation Needs & Layout & Dimension * & Location \\
\hline Aaby et al. [49] & 2004 & USA & Smallpox & Not available & $\begin{array}{l}\text { Triage station outside the center where } \\
\text { linear flow split in two lines according } \\
\text { to medical history, registration station, } \\
\text { waiting rooms with educational } \\
\text { videos, screening station, consultation } \\
\text { station (only for people with } \\
\text { comorbidities), } \\
\text { vaccination station, exit }\end{array}$ & Not available & School \\
\hline Andress, et al. [50] & 2003 & USA & Smallpox & $\begin{array}{l}\text { Strategy meetings; visit the potential } \\
\text { sites; training involved personnel, staff } \\
\text { distinctive vest for personnel }\end{array}$ & $\begin{array}{l}\text { Vaccine storage, triage, screening, } \\
\text { education, isolation, vaccination, } \\
\text { computer entry, with signs identifying } \\
\text { the stations }\end{array}$ & 105,000 square foot & Shopping mall \\
\hline Asllani et al. [51] & 2007 & USA & Influenza & $\begin{array}{l}\text { Trained personnel, transportation, } \\
\text { equipment, retrieve available } \\
\text { guidelines, vaccines, visits to the } \\
\text { potential sites and investigate } \\
\text { the layout }\end{array}$ & $\begin{array}{l}\text { Registration immediately after } \\
\text { entrance, waiting rooms with } \\
\text { educational videos, medical evaluation } \\
\text { rooms, vaccination station, and exit }\end{array}$ & Not applicable & Computer simulation \\
\hline Asllani et al. [52] & 2007 & USA & Influenza & $\begin{array}{l}\text { transportation vehicles, medical and } \\
\text { assistant equipment such } \\
\text { as wheelchairs }\end{array}$ & $\begin{array}{l}\text { Entrance, registration area, waiting } \\
\text { rooms with educational videos, } \\
\text { vaccination room or medical } \\
\text { evaluation area for those with } \\
\text { comorbidities, waiting room and exit }\end{array}$ & Not applicable & Computer simulation \\
\hline Gupta et al. [54] & 2009 & USA & Influenza & Not available & $\begin{array}{l}\text { Arrival, consent hand out lane, consent } \\
\text { form filled in lane, vaccination at the } \\
\text { point of dispense, detour and depart }\end{array}$ & $\begin{array}{l}\text { Vehicle gap length } 12 \text { feet, } \\
\text { length of the consent form } \\
\text { lane } 950 \text { feet, length of } \\
\text { vaccination lane } 50 \text { feet }\end{array}$ & $\begin{array}{c}\text { Drive-through clinic at } \\
\text { a stadium }\end{array}$ \\
\hline Ha et al. [55] & 2014 & USA & Influenza & $\begin{array}{l}\text { Standardized training for personnel, } \\
\text { meeting, staff distinctive vest } \\
\text { for personnel }\end{array}$ & $\begin{array}{l}\text { Linear flow split in two lines according } \\
\text { to medical history; with signs } \\
\text { identifying the stations }\end{array}$ & Not available & Auditorium \\
\hline Jenlink et al. [56] & 2009 & USA & Influenza for children & $\begin{array}{l}\text { Promotional campaign to the } \\
\text { population only when sure about } \\
\text { vaccine supply. One lot per day for } \\
\text { each center in order to print the lot } \\
\text { number on all the form and save time. } \\
\text { Determine target population for the } \\
\text { vaccine. Secure supply }\end{array}$ & $\begin{array}{l}\text { Unidirectional linear flow from } \\
\text { gathering area, multiple stations for } \\
\text { eligiblity, screening, completition and } \\
\text { review form, and perform vaccination; } \\
\text { and } 1 \text { post-vaccination area }\end{array}$ & Not available & School \\
\hline
\end{tabular}


Table 1. Cont.

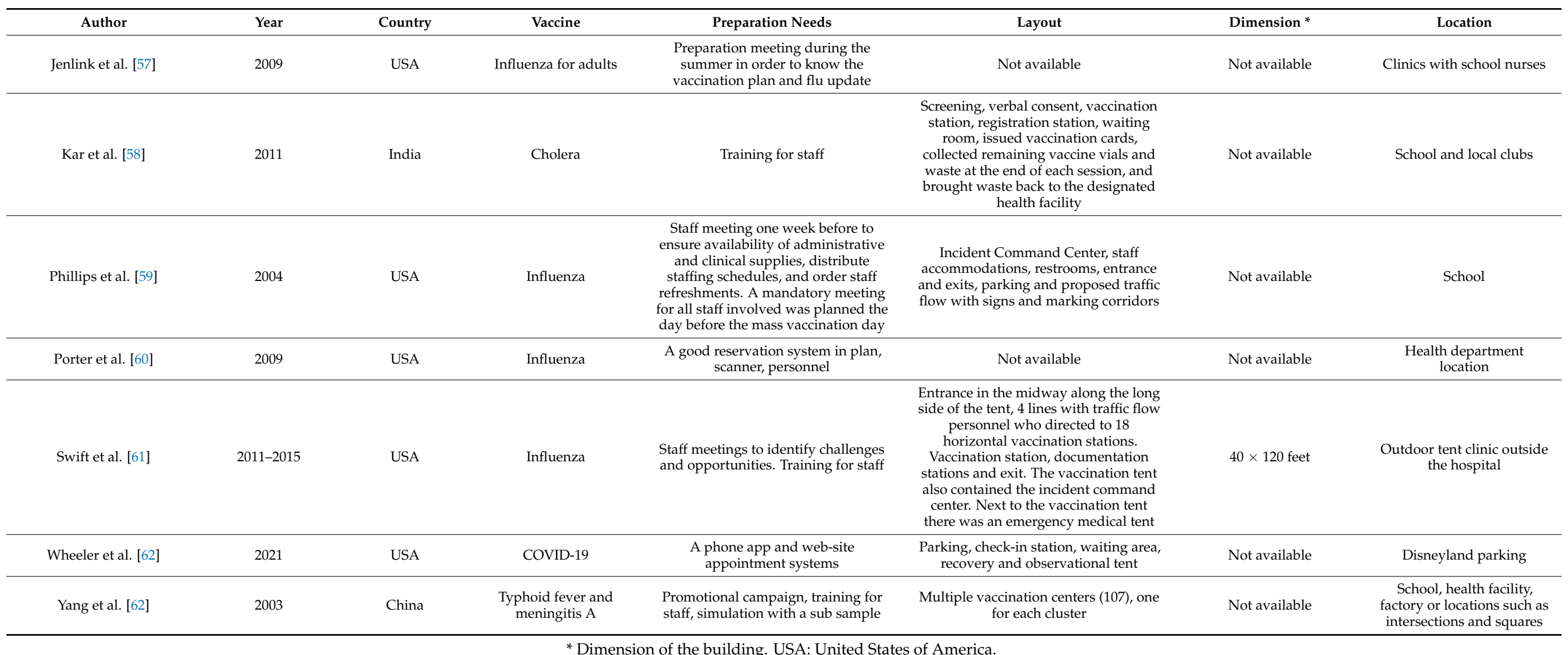

* Dimension of the building. USA: United States of America. 


\subsection{Preparation Needs}

To set up an MVC, several important organizational aspects must be considered, and, as a starting point, several studies [53-57,60,61] used the Center for Disease Control and Prevention (CDC) guidelines [11]. These guidelines were mainly developed for a largescale influenza vaccination campaign and suggested structuring the entire flow in four main steps. The first is orientation: people should be guided by traffic flow personnel when arriving at the center, and they should be screened for potential symptoms. Step two involves staff support in filling forms and assessment of contraindications. Step three is the vaccination; and the fourth step is the post vaccination observation, during which personnel can answer remaining questions, inform about vaccination schedules, and exit. Interestingly, despite the relevance of the vaccination site, only two articles underlined the importance of identifying, inspecting and evaluating the potential site [50,51]. Similarly, only two articles $[50,58]$ analyzed the aspect of the reception and transport of the vaccine: the first considered the mode of transportation and percentage of vaccines that may break or spoil during this process, while the second identified pharmacists and safety officials as professional figures in charge of the process. In detail, the safety officials were responsible for opening, inventorying and transporting vaccines to the mass vaccination center, where pharmacists reconstituted the vaccine.

On the other hand, a larger share of collected reports focused on the human factor of mass vaccination campaigns, as five articles highlighted the importance of preventive identification of the required personnel $[49,50,52,58,59]$, while seven of them $[50,55,57-59,61]$ suggested the need for meetings in the period preceding the actual start of vaccine delivery. More precisely, Andress et al. [50] highlighted the importance of identifying consultants, educators and personnel; Jenlink et al. [57] of the updated status of vaccination plans and disease data; and Swift et al. [61] of identifying challenges and opportunities. A total of nine articles [50,51,53,55,57-59,61,63] stressed the necessity of personnel training, not only on operating procedures such as vaccination storage and recombination of the vaccine, but also in data entry [53].

The types of equipment necessary to the MVC were detailed by a total of five reports, with recommendations focusing on communication (i.e., phones and fax, two-way radios, communication hardware and software) $[50-52,55,59]$, logistical (e.g., portable toilets; wheelchairs, etc.) [50,51], and medical assets (i.e., medical and medical assistant personal protective equipment, staff member vests) that also included items often overlooked such as video/DVD players and video monitors [50,52,55,59]. Additionally, four articles underlined the importance of having registration forms and informational videos in multiple different languages $[49,56,57,59]$. Interestingly, the collected reports suggest that staff member vests are important not only as part of the personal protective equipment of MVC personnel, but also for allowing the easy and clear identification of their role by patients.

Moreover, a total of three articles $[56,58,63]$ reported the implementation of a prior and well-structured promotional and educational campaign specifically aimed at the target population. This intervention could contribute to ensuring or improving the success of a mass vaccination campaign by stressing the social and practical importance of the coveted goal of herd immunity.

\subsection{Layout}

All included articles analyzed the MVC location and layout, the latter intended as how it is designed or arranged and its internal organization. In just three studies $[60,61,63]$ the vaccination center was inside a hospital; in contrast, in the majority of them [49,53-59,62,63], it was in a building not normally used for healthcare purposes, for instance, schools, clubs, shopping malls, factories, stadia, squares, and auditoriums. The areas and rooms needed inside and outside the vaccination center were described in nine studies [49-52,55,56,59,61,62]; overall, it emerged that they were parking, entrance, registration area, triage, waiting rooms (where people stay both before and after vaccination), educational area, medical evaluation rooms, vaccine storage, vaccination station, post-vaccination area, and exit. An 
outdoor triage station and/or an observational tent out of the main building were irregularly reported $[49,61,62]$. Furthermore, an emergency medical tent staffed with paramedics and emergency medical technicians could be placed, even outside of the main building [61]. The importance of signage was stressed in several articles and it was identified as one of the most critical and frustrating aspects of the whole implementation [50-52,54,57,59,62]. Not coincidentally, three studies $[50,55,61]$ suggested drawing signs identifying the stations and barrier tape to guide patients through the process, while five articles suggested to objectively show the layout through a site map [51-53,55,61].

Relative to the internal organization, many articles gave some important advice listed below. While subjects are in the waiting rooms, they can view educational videos and/or read and complete forms on the clipboard provided [49-52]. One study concluded that in order to facilitate the obtaining of an optimal vaccination rate, the vaccinator should seat between the two seated patients, with a drawer that should stay on the other side of the room ensuring a steady supply of the vaccine [53]. Among the 15 retrieved articles, 4 articles described the flow that patients should follow to best identify available vaccination stations: two of them $[49,55]$ suggested a linear patient flow divided in two lines according to medical history (patients with or without possible contraindications) - patients who have possible complications based on their medical history go to the consultation station; the others sign a consent form and go directly to the vaccination station. The third article [56] described a unidirectional linear flow from the gathering area, multiple stations for eligibility, screening, completion and review form, vaccine administration, and one post-vaccination area. The fourth article [61] split patients in four lanes greeted by a staff member for each lane who directed them to 18 vaccination stations distributed horizontally. The Incident Command Center was described in two articles, and it was responsible for coordinating communications and resources [59,61]. Interestingly, one article [54] described a completely different type of mass vaccination center: a drive-through clinic. This was presented by the authors as an efficient method for delivering, in a quick and safe manner, vaccines to a mass of people, and it was considered extremely important in case of highly contagious infections, like COVID-19. Nevertheless, their internal organization appeared to be similar to the others, and it is composed of arrival, consent hand out lane, consent form fills in lane, vaccination at the point of administration, detour and depart.

\subsection{Dimensions of Mass Vaccination Center}

Four articles indicated the dimensions of the MVC [50,52,54,61]; in more detail, two of them gave the dimensions for each room and its capacity [52,54], the others just the total size $[50,61]$. Interestingly, the total dimension range varies between 4800 and 105,000 square feet.

\subsection{Pharmacy Room}

Across all the included studies, five $[50,55,56,58,63]$ stressed the presence of a pharmacy room in order to store the vaccine in standardized boxes. Specifically, they described the number of refrigerators and freezers [63], and refrigerated transportation [56,58]. The general recommendation was to put the vaccination stations close together and near the supply box [55]. More details are provided in Table 2. 
Table 2. Detailed description of the rooms, role and performance of the mass vaccination centers presented in the included studies.

\begin{tabular}{|c|c|c|c|c|c|c|c|c|}
\hline Author & Pharmacy Room & Restrooms & $\begin{array}{l}\text { Waiting Room } \\
\text { Capacity and } \\
\text { Management }\end{array}$ & Staffing & Medical Procedures & Timing/Performance & Others & Map \\
\hline Aaby et al. [49] & $\begin{array}{c}\text { Vaccines stored at the } \\
\text { logistic hub at Hechi } \\
\text { CDC: a } 3 \times 12 \mathrm{~m}^{2} \text { room } \\
\text { equipped with } 8 \\
\text { refrigerators and } \\
1 \text { freezer }\end{array}$ & Not available & Not available & $\begin{array}{l}\text { Staff number needed } \\
\text { for each stage: } \\
\text { triage: } 5 \text {; registration:8; } \\
\text { education: } 8 ; \\
\text { screening: } 9 ; \\
\text { consultation: } 6 ; \\
\text { vaccination: } 16\end{array}$ & $\begin{array}{l}\text { Injection performed by } \\
\text { nurses. Medical history } \\
\text { collectors not available }\end{array}$ & $\begin{array}{l}\text { Time for each stage: } \\
\text { triage: } 2: 18 ; \text { registration: } \\
\text { 2:43; education: } 31: 23 ; \\
\text { screening: } 16: 77 ; \\
\text { vaccination: } 8: 87 ; \text { total in } \\
\text { system } 60: 02 \\
\text { Working time: } \\
\text { 2:30 p.m.-3 p.m. }\end{array}$ & Not available & No \\
\hline Andress, et al. [50] & $\begin{array}{l}\text { Forecasted without } \\
\text { details }\end{array}$ & $\begin{array}{l}\text { Large enough in order } \\
\text { to guarantee } \\
\text { accessibility for all }\end{array}$ & Not forecasted & $\begin{array}{l}140 \text { in total, including } \\
\text { human resources } \\
\text { manager, translators, } \\
\text { security and nurses }\end{array}$ & $\begin{array}{c}\text { Medical history } \\
\text { collection and vaccine } \\
\text { injection performed by } \\
\text { medical staff (nurses } \\
\text { and physicians) }\end{array}$ & $\begin{array}{l}104 \text { vaccinations in } 2 \mathrm{~h} \\
\text { (it was a } 2 \text {-h exercise) }\end{array}$ & Not available & No \\
\hline Asllani et al. [51] & Not available & Not available & Not available & Not available & Not available & $\begin{array}{l}50,000 \text { vaccinations in } \\
3 \text { days }\end{array}$ & $\begin{array}{l}\text { Creation of a network } \\
\text { among the mass } \\
\text { vaccination centers in } \\
\text { order to share resources } \\
\text { dynamically }\end{array}$ & Yes \\
\hline Asllani et al. [52] & Not available & Not available & Not available & Not available & Not available & $\begin{array}{l}700 \text { vaccinations per hour; } \\
\text { vaccination session lasted } \\
24 \mathrm{~h} \text {. Time for each stage for } \\
\text { person: registration } 30-90 \mathrm{~s}, \\
\text { registration form } 2 \mathrm{~min}, \\
\text { video watch } 3-5 \mathrm{~min}, \\
\text { medical evaluation } \\
2-10 \text { min, vaccine } \\
\text { administration } 2-4 \mathrm{~min}\end{array}$ & Not available & Yes \\
\hline Caum et al. [53] & Not available & Not available & $\begin{array}{l}\text { Stores of emergency } \\
\text { medical materials; } \\
\text { capacity not available }\end{array}$ & $\begin{array}{l}1 \text { vaccinator, } 1 \text { drawer, } \\
1 \text { data collector with a } \\
\text { range of vaccination } \\
\text { stations up to } 14 . \\
\text { Presence of a human } \\
\text { resources manager to } \\
\text { supervise the tasks of } \\
\text { each staff ensuring that } \\
\text { everyone understood } \\
\text { their role }\end{array}$ & $\begin{array}{c}\text { Data collectors } \\
\text { interviewed the } \\
\text { students. Injection } \\
\text { performed by } \\
\text { vaccinator (not } \\
\text { otherwise specified) }\end{array}$ & $\begin{array}{l}32-45 \text { people for each } \\
\text { vaccination station per hour; } \\
\text { vaccination session lasted } \\
\text { 1:30 (1:05-2:35 p.m.). In total } \\
52 \text { people in } 54 \text { min }\end{array}$ & $\begin{array}{l}\text { Preference of electronic } \\
\text { data entry }\end{array}$ & Yes \\
\hline Gupta et al. [54] & Not available & Not available & Not available & Not available & $\begin{array}{l}\text { Consent form workers } \\
\text { who distributed and } \\
\text { received the filled-out } \\
\text { consent forms. } \\
\text { Injection performed by } \\
\text { medical workers }\end{array}$ & $\begin{array}{l}7732 \text { vaccinations in a } 12 \mathrm{~h} \\
\text { (7 a.m.- }-7 \text { p.m.); } 12,613 \\
\text { served via } 10 \text { drive-through } \\
\text { lanes after two days. Time } \\
\text { for each person: } \\
27.4+/-0.8 \text { min }\end{array}$ & Not available & No \\
\hline
\end{tabular}


Table 2. Cont.

\begin{tabular}{|c|c|c|c|c|c|c|c|c|}
\hline Author & Pharmacy Room & Restrooms & $\begin{array}{l}\text { Waiting Room } \\
\text { Capacity and } \\
\text { Management } \\
\end{array}$ & Staffing & Medical Procedures & Timing/Performance & Others & Map \\
\hline Ha et al. [55] & $\begin{array}{c}\text { Store vaccines in } \\
\text { standardized boxes, } \\
\text { placed where trained } \\
\text { staff exactly know. } \\
\text { Vaccination stations } \\
\text { placed closer together } \\
\text { and near the supply } \\
\text { box }\end{array}$ & Not available & Not available & 40 in total & $\begin{array}{l}\text { Medical history } \\
\text { collected by nurses or } \\
\text { healthcare providers. } \\
\text { Injectors not available }\end{array}$ & $\begin{array}{l}4500 \text { vaccinations in } 6 \mathrm{~h} \\
\text { (time for each vaccination } \\
\text { session). Working days: } 3\end{array}$ & Not available & Yes \\
\hline Jenlink et al. [56] & $\begin{array}{l}\text { Strict regulation of } \\
\text { thermometers. } \\
\text { Attention to the } \\
\text { refrigerated } \\
\text { transportation }\end{array}$ & Not available & $\begin{array}{l}15 \text { min of observation; } \\
\text { capacity not available }\end{array}$ & $\begin{array}{l}\text { Nurses paid and on a } \\
\text { voluntary basis } \\
\text { (nursing students). For } \\
\text { each vaccinator } 4 \\
\text { nonmedical staff useful } \\
\text { as greeters, traffic } \\
\text { direction, form review, } \\
\text { and supply runners. } \\
\text { School staff to obtain } \\
\text { consent for vaccination } \\
\end{array}$ & $\begin{array}{l}1 \text { to } 10 \text { rooms each with } \\
5 \text { to } 6 \text { nurses for } \\
\text { screening and checking } \\
\text { the form and vaccinate }\end{array}$ & $\begin{array}{l}2500 \mathrm{~s} \text { doses in } 3 \mathrm{~h} \text { (time for } \\
\text { vaccination session). Time } \\
\text { for each person: } 30 \mathrm{~min}\end{array}$ & $\begin{array}{l}\text { School was a good } \\
\text { location for child } \\
\text { vaccination because } \\
\text { guardians/parents did } \\
\text { not need to take time } \\
\text { off from work }\end{array}$ & No \\
\hline Jenlink et al. [57] & Not available & Not available & $\begin{array}{l}15 \text { min of observation; } \\
\text { capacity not available }\end{array}$ & $\begin{array}{l}\text { School staff to obtain } \\
\text { consent for vaccination. } \\
\text { Nurses to check the } \\
\text { consent form }\end{array}$ & Not available & $\begin{array}{l}\text { 11,200 vaccinations in } 5 \mathrm{~h} \\
\text { for the } 9 \text { clinics. } 100 \\
\text { appointments for every } \\
5-8 \text { min settled by the call } \\
\text { center dedicated. Working } \\
\text { days: } 3 \text { weeks, during the } \\
\text { evening or on Saturday }\end{array}$ & Not available & No \\
\hline Kar et al. [58] & Not available & Not available & Not available & $\begin{array}{l}395 \text { health } \\
\text { workers/volunteers } \\
\text { organized in team }\end{array}$ & Not available & $\begin{array}{l}\text { Working time: } 7: 00 \\
\text { a.m. }-5: 00 \text { p.m. for } 3 \\
\text { consecutive days in each } \\
\text { round from } 5 \text { May to } 4 \text { June } \\
2011 \text { (in total } \\
15 \text { working days) }\end{array}$ & $\begin{array}{l}\text { The walk-in cooler } \\
\text { temperature was } \\
\text { monitored and } \\
\text { maintained between }+2 \\
\text { to }+8 \mathrm{C}\end{array}$ & No \\
\hline Phillips et al. [59] & Not available & Not available & Not available & $\begin{array}{l}36 \text { nurses, } 10 \text { personals } \\
\text { to record electronically } \\
\text { data, } 2 \text { persons to greet } \\
\text { at the entrance, } 5 \text { traffic } \\
\text { flow personnel, } \\
15 \text { persons to screen for } \\
\text { vaccine eligibility, } \\
2 \text { persons to maintain } \\
\text { real time hourly } \\
\text { vaccine counts }\end{array}$ & Not available & $\begin{array}{c}640 \text { vaccinations per hour; } \\
\text { each vaccination session } \\
\text { lasted } 8 \mathrm{~h}(8: 20 \text { a.m.- }-5 \text { p.m.). } \\
\text { Working days: } \\
2 \text { consecutive Saturdays }\end{array}$ & $\begin{array}{l}\text { The fire department } \\
\text { provided a basic life } \\
\text { support ambulance on } \\
\text { sire, and voluntary } \\
\text { companies provided } \\
\text { refreshments from a } \\
\text { fully equipped } \\
\text { service vehicle }\end{array}$ & No \\
\hline
\end{tabular}


Table 2. Cont.

\begin{tabular}{|c|c|c|c|c|c|c|c|c|}
\hline Author & Pharmacy Room & Restrooms & $\begin{array}{l}\text { Waiting Room } \\
\text { Capacity and } \\
\text { Management }\end{array}$ & Staffing & Medical Procedures & Timing/Performance & Others & Map \\
\hline Porter et al. [60] & Not available & $\begin{array}{c}\text { Breaks and lunches } \\
\text { coordinated by area } \\
\text { supervisors }\end{array}$ & Not available & $\begin{array}{l}1 \text { vaccine preparator for } \\
4 \text { vaccinators, } \\
133 \text { physicians, } \\
43 \text { vaccinators, } \\
11 \text { vaccine preparer, } \\
77 \text { administrative staff }\end{array}$ & $\begin{array}{l}\text { Medical history } \\
\text { collected by staff. } \\
\text { Injection performed } \\
\text { by nurses }\end{array}$ & $\begin{array}{c}7889 \text { vaccinations in } 9.5 \mathrm{~h} \\
\text { (time for each vaccination } \\
\text { session). Time for each } \\
\text { person: } 15 \mathrm{~min}\end{array}$ & Not available & No \\
\hline Swift et al. [61] & Not available & $\begin{array}{l}\text { A staff break room } \\
\text { stocked with snacks } \\
\text { and beverages }\end{array}$ & $\begin{array}{l}\text { Tent located adjacent to } \\
\text { the vaccination clinic; } \\
\text { capacity not available }\end{array}$ & $\begin{array}{l}\text { Leaders from } \\
\text { occupational health, } \\
\text { nurses, pharmacists, } \\
\text { student health, supply } \\
\text { management, human } \\
\text { resources, safety and } \\
\text { event officers }\end{array}$ & $\begin{array}{l}\text { Injection performed by } \\
\text { nurses or pharmacists } \\
\text { or nursing or pharmacy } \\
\text { students certified to } \\
\text { administer } \\
\text { intramuscular } \\
\text { injections. Medical } \\
\text { history collectors } \\
\text { not available }\end{array}$ & $\begin{array}{c}12,850 \text { with } 37.1 \text { vaccines } \\
\text { per vaccinator } / \text { hour. Each } \\
\text { vaccination session lasted } \\
8 \mathrm{~h}(10 \text { a.m.- }-4 \text { p.m.). } \\
\text { Working days: } \\
\text { 1-2 days/year per } 5 \text { years } \\
\text { in total }\end{array}$ & $\begin{array}{c}\text { Each vaccination } \\
\text { station was supplied } \\
\text { with a flag system } \\
\text { allowing vaccinators to } \\
\text { raise color-coded flags } \\
\text { Job action sheet were } \\
\text { provided to the staff. } \\
\text { Prefer one location in } \\
\text { order to facilitate staff } \\
\text { management, supply } \\
\text { and avoid surplus or } \\
\text { shortages in one of } \\
\text { the centers }\end{array}$ & Yes \\
\hline Wheeler et al. [62] & Not available & Not available & $\begin{array}{l}\text { Tent with medical staff; } \\
\text { capacity not available }\end{array}$ & Not available & Not available & $\begin{array}{l}7500-8000 \text { vaccinations for } \\
\text { each vaccination session. } \\
\text { Time for each person: } \\
30 \mathrm{~min}\end{array}$ & Not available & No \\
\hline Yang et al. [62] & Not available & Not available & $\begin{array}{c}15 \text { min of observation } \\
\text { monitored } \\
\text { by physicians; capacity } \\
\text { not available }\end{array}$ & $\begin{array}{c}30 \text { physicians, } \\
43 \text { nurses, } 24 \text { other } \\
\text { health workers and } \\
9 \text { nonhealth workers to } \\
\text { record data, } \\
78 \text { community helpers } \\
\text { to facilitate the process. } \\
\text { Each cluster was } \\
\text { provided by a team } \\
\text { based on one physician, } \\
\text { one nurse, one recorder } \\
\text { and one } \\
\text { community helper }\end{array}$ & $\begin{array}{l}\text { Injection performed by } \\
\text { nurses. Medical history } \\
\text { collectors not available }\end{array}$ & $\begin{array}{l}200 \text { vaccinations for each } \\
\text { cluster per day. Working } \\
\text { days: } 31 \text {, from } 8 \text { April to } \\
12 \text { May } 2003\end{array}$ & $\begin{array}{l}\text { Each vaccination center } \\
\text { administered only } \\
\text { one vaccine }\end{array}$ & No \\
\hline
\end{tabular}




\subsection{Restrooms}

Restrooms for personnel, such as lunch and break rooms, stocked with food and beverages, were considered as a relevant part of the MVC in three articles [50,60,61]. As general features, they should be large enough in order to guarantee safe accessibility for all the personnel [50]. In order to improve their usability, coordination by an area supervisor was sometimes recommended [60].

\subsection{Staffing and Medical Procedures}

Among all included articles, 11 described the type and/or competences of staff needed in a mass vaccination center $[49,50,53,55-61,63]$. In particular, the most frequently reported were physicians, nurses and pharmacists among medical staff, whereas traffic flow personnel, data collection personnel, and volunteers (nursing students, community helpers or school staff for those who implemented the vaccination center in a school) among nonmedical staff. Moreover, in three articles, authors highlighted the importance of human resources managers to supervise the tasks of each staff member and ensure that everyone understood their role $[50,53,61]$.

Regarding the pre-vaccination visit, most of the articles generically referred to a data collector, whereas only three studies specified that the visit was performed by medical staff, including either physicians or nurses $[50,55,56]$. Regarding the medical staff actually performing the vaccination shot, the majority of the articles generically reported on "vaccinators", not otherwise specifying their professional requirements. On the contrary, two articles employed the even more vague term of "medical staff", while only 5 articles out of the 15 we collected clearly stated that vaccinators were nurses $[49,56,60,61,63]$, pharmacists, or nursing and pharmacy students certified to administer intramuscular injections [61]. Conversely, physicians were mainly involved in the post-vaccination tasks, monitoring the acute adverse events following immunizations. The waiting time was usually $15 \mathrm{~min}[56,57,63]$ and the room was equipped with emergency medical materials [53].

\subsection{Timing and Performance}

Regarding timing and performance, collected data were quite heterogeneous. Among the 15 retrieved articles, 3 of them $[54,60,62]$ reported the total time needed for the vaccination process, from which a range of $14-30 \mathrm{~min}$ for each subject was eventually calculated. On the other hand, two articles $[49,52]$ specifically indicated the targeted time needed for each stage of the vaccination process. On average, triage required $2 \mathrm{~min}$, registration $3 \mathrm{~min}$, receiving educational videos 3-5 min, medical evaluation $2-10 \mathrm{~min}$, and vaccine injection required 2-4 min. In order to have a final tally of how many vaccinations could be done for each vaccination session, five articles specified the number of vaccinations per hour [52,54-56,59], with an estimated capacity of around 713 vaccinations per hour. Interestingly, the performance of the drive-through clinic [54] reported a similar result with 12,613 vaccinations, served via 10 drive-through lanes, in 2 days with 12 working hours each.

More in detail, one article [59] reported 640 vaccinations per hour with a staff composed of 36 nurses, 10 recording data electronically, 2 people to greet at the entrance, 5 traffic flow personnel, 15 persons to screen for vaccine eligibility and 2 to maintain real time hourly vaccine counts. In the latter vaccination center, each vaccination session lasted $8 \mathrm{~h}$. Lastly, three articles $[53,61,63]$ reported the number of administered vaccines per vaccinator per hour or per day, from which emerges that the average is about 264 for each vaccination station per day, considering 8 working hours.

Few of the retrieved articles reported weekly opening days because most of them were simulations of massive vaccination centers or single-day experiences.

\section{Discussion}

Results of our rapid review highlighted the high heterogeneity around the characteristics, layout and management of an MVC. Moreover, only a few articles were retrieved, 
and almost all of them did not refer to the COVID-19 vaccination campaign, reporting on previous vaccination campaigns that were hardly comparable in terms of targeted population and logistic issues-for example, the necessity to respect all of NPI during all of the vaccination procedures in order to avoid the spread of the pathogen because of the mass gathering represented by the MVC themselves. Interestingly, some of the available guidelines on SARS-CoV-2 vaccination centers (e.g., Quebec Health Ministry, German Committee on the Protection from Biological Agents, or ABAS, but also the Operating Framework of British National Health Service) have clearly recognized such relationship, and the potential shortcomings $[12,64,65]$. Despite the overall heterogeneity found, some aspects can be considered as a core element of an MVC and, not coincidentally, have been implemented by the aforementioned national guidelines.

Firstly, in most of the cases, an MVC could be started up in sites that are not originally designed for providing healthcare services. Secondly, an MVC may be only temporarily used, with the aim to centralize as much as possible the vaccination procedures, ensuring high volumes in the shortest time period. In fact, a single vaccination center, instead of multiple locations, might facilitate staff management, supply and avoid surplus or shortages in one of the centers [61]. However, in the case of multiple centers, Asllani et al. suggested to create a network among the MVCs in order to share resources dynamically [51], but such a recommendation has been only acknowledged by Quebec guidelines [12]. In light of this, we suggest a potential definition of an MVC, i.e., a location normally used for non-healthcare-related activities set up for high-volume and high-speed vaccinations during infectious disease emergencies. Examples of mass vaccination sites could include stadiums, exhibition and convention halls, airports, stations, theme parks, museums, and universities or other temporary indoor or outdoor facilities. Particularly in European settings, where an older and aged population may find growing difficulties to reach facilities that are often located in peripheral areas, relatively smaller but widely spread structure may be particularly useful-for example, churches/religious structures and schools [65]. In this regard, a school could be considered a particularly good location for child vaccination because guardians/parents do not need to take time off from work, and this aspect could increase velocity and vaccine acceptance [56,66-68], particularly if available vaccines against SARS-CoV-2 will be eventually licensed for children and adolescents [69].

However, as available studies were largely focusing on pathogens other than SARS$\mathrm{CoV}-2$, some of the aforementioned options may be only partially appropriate. For example, German ABAS has recently stressed the importance of prioritizing facilities where the implementation of SARS-CoV-2 specific NPI was guaranteed through appropriate distancing, ventilation, appropriate access and waiting spaces [64].

Another relevant issue is the number, role and type of staff enrolled. Despite the fact that vaccination is a medical procedure, the vast majority of personnel involved were the nonmedical staff. Indeed, the most critical aspects that need to be carefully managed are those related to logistics regarding both supplies and people. Regarding supplies, the most important aspect is quite obviously the availability of a sufficient amount of vaccines, their reception and internal management, including their safe storage, particularly in terms to temperature control. In this regard, COVID-19 vaccines have some specific requirements. Indeed, mRNA-based vaccines require extreme-cold storage conditions, while adenovirus-based vaccines can be stored either in liquid or freeze-dried form, at temperatures (respectively $-18{ }^{\circ} \mathrm{C}$ and $2-8{ }^{\circ} \mathrm{C}$ ) that are compatible with a more conventional cold chain [70]. Moreover, the high precision required in vaccine reconstitution necessitates dedicated areas, as well as highly trained personnel. Because these requirements are specific for some of SARS-CoV-2 vaccines, they were not clearly addressed in most of available studies on MVCs; however, quite surprisingly, this significant shortcoming was only irregularly reported in available guidelines. For example, British NHS framework clearly states that a vaccination center must "ensure a sufficient fridge capacity for vaccines, 
that the areas is secure and there is an area suitable for vaccine preparation" [65], while no specific recommendations are reported by Quebec and German recommendations [12].

Regarding the human factor, the main issues are related to the simultaneous mobilization of large groups of individuals, which only partially could be equated to a mass gathering event. In fact, on one hand, controlling both inside and outside flow through draw signs identifying the stations, the use of barrier tape to guide patients, traffic flow personnel (inside) and personnel from the department of social security (outside) is fundamental especially in managing arrival rate, mode of transportation, point of dispatching and general traffic condition [50-52,54,57,59,62]. On the other hand, these people might need health information, reassurance on vaccine safety and efficacy [71], clarification on doubts, and assistance throughout the process [72]. Even though this specific point has been previously stressed by available studies, it has only been scarcely addressed by available recommendations, with potentially severe consequences [71]. In fact, while earlier reports suggested that the COVID-19 vaccination could be well received by the general population [73,74], a growing body of evidence, particularly from USA and Europe, suggests that a large share of the general population may exhibit substantial vaccination hesitance toward COVID-19 vaccination because of paved side effects (as thrombosis) or due to the rapidity by which vaccines have been issued $[75,76]$. For this reason, some authors suggested using educational videos during the waiting phase before vaccination. In general, clear and frequent communication with the public and staff is crucial for the successful implementation and delivery of immunization clinic operations $[72,77,78]$. To achieve this goal, duplication of vaccine educational signage and content in other commonly spoken languages is needed. Indeed, it is fundamental to assist people in their specific language in order to guide them throughout the immunization processes. In this regard, some guidelines have somewhat overtaken original reports from scientific literature, pointing towards an extensive use of pictorial representations in order to overcome potentially reduced literacy even in the original vehicular language of migrants and minorities [12,65]. In some cases, onsite translators/interpreters or telephone translation services have been used [79]. Although only four articles dwelled on this specific aspect [49,56,57,59], considering that such reports referred to MVCs located in areas where several languages are spoken (USA, China), and stating that it was specifically addressed by some guidelines, it can be speculated that this potential shortcoming may be widespread, representing a routinary issue not needing to be specifically discussed. Indeed, taking the example of the USA, signage, educational contents for patients, and vaccine educational campaigns were conducted in at least two languages, English and Spanish, as well as potentially several others depending on local community demographics. In particular, one article [56], describing the experience of an MVC in a public school located in Virginia, referred to 121 languages to be taken into consideration. Specifically, information line staff sent communications home in English and Spanish, but with a special message on the envelope in the most common other languages, informing families that this was important information they should have translated. Instead, with fewer languages to consider, Minneapolis (Minnesota) translated materials into Hmong, Somali, and Spanish specific to each school's population and had interpreters available in MVCs [56]. Nevertheless, nurses, nursing students and generally trained personnel were also involved in helping individuals to fill in the consent form, checking for correctness, and screening for vaccine eligibility. Indeed, two studies used a different approach according to which, based on medical history (subjects with or without contraindications), subjects were immediately directed to vaccination in case of no contra-indications, or to the consultation station in case of contra-indications. In light of this, training personnel is extremely important. Andress et al. [50] clearly reported which type of information should be targeted by which professionals: public health experts to delivery information regarding vaccination plan; veterinarians for describing biological outbreak containment; nurses to demonstrate vaccination procedures; pharmacists to teach about storage and reconstitution of the vaccine. Accordingly, Swift et al. [61] supplied each vaccination station with a job action sheet including specific steps, role and responsibility 
of each staff member. Additionally, Caum et al. [53] suggested training personnel also in electronic data entry. Indeed, even if electronic data entry might increase the burden in the short term, it highly increases the usability of data collected for estimation of vaccination coverage and other statistics [80]. Nevertheless, ensuring a good quality of electronic data record remains fundamental in the whole process.

Another important aspect found is the layout of the center. Despite the slight differences retrieved among the articles, the most common aspects were entrance, registration, waiting rooms (in many cases with educational video), screening/anamnesis, vaccination room, post vaccination room, and exit. Moreover, a unidirectional linear flow from entrance to exit was the most used, but only in one case where the vaccination stations were positioned horizontally [61]. This is a crucial point to consider when planning the vaccination center, especially in cases of epidemic scenarios with highly contagious and infectious pathogens like SARS-CoV-2. Indeed, to prevent transmission of COVID-19 at MVCs, it will be essential to minimize crowding, ensure physical distancing and separate the different areas. Best practices in spacing clients and minimizing crowding include personnel directing people flow, online and phone appointments and registration, wristbands or ticket number [65]. Moreover, people could wait outside the center for their appointment, evaluating options such as tents and heaters during the winter or inclement weather. The post-immunization waiting area could be a potential location where people, kept under observation for at least $15 \mathrm{~min}$ to monitor for immediate vaccine reactions, may be too close together. Therefore, MVC should be organized in order to isolate incoming people from the others and to ensure they are at least $2 \mathrm{~m}$ apart at all times with their masks on. All these social distancing rules should be adhered to throughout the model for both safety and privacy issues. Despite the high importance of all these aspects, they only partially emerged from our review because only one article described the COVID-19 vaccination center and all the others referred to other microorganisms with a different infection rate [62]. Another consideration that we can raise from this review is that even the extremely high importance of simultaneously managing a large number of individuals, the size of the center, as well as the need to identify and to inspect in advance the potential site was marginally reported on by a very small number of studies $[50,51,54,61]$. This aspect could be explained because almost all the included studies reported simulation or single-day experiences. However, although the effectiveness of this approach can be quite limited, simulation offers an excellent and relatively inexpensive opportunity to test alternative scenarios analysis and to develop effective solutions to management problems. Indeed, the simulation outputs visually and numerically show the processing and waiting times, number of cars and people that can be served under different situations. Computer simulations can be considered as pivotal tools in modeling different operational solutions for complications that can occur in any of the critical vaccination phases. Indeed, the high degree of dynamic uncertainties can be forecasted, helping planners to visualize what would happen. Lastly, just one article described the organization and performance of a drive-through mass vaccination center. Even taking into consideration the paucity of evidence, this layout could be considered particularly suitable for the current highly contagious pandemic because it allows a high level of isolation among subjects that do not need to exit their own cars.

\section{Strengths and Limitations}

Before generalizing our results, some strengths and limitations should be addressed. The first strength of our work is the systematic but rapid approach used. Indeed, rapid reviews are an emergent method used to collect, analyze and interpret available evidence. This is especially true nowadays, when the digitalization and the rapidity of evidence production call for a continuous update of available knowledge [81]. In this context, rapid reviews are extremely useful for collecting emerging evidence that can be promptly used by policymakers to inform their decisions, particularly when difficult decisions have to be made in circumstances of emergency, such as the current COVID-19 pandemic. However, despite being systematic in nature, our review was limited to only four databases. 
Nevertheless, we assessed five databases overcoming the minimum standards (at least two) set by the PRISMA guidelines for systematic reviews. Secondly, we did not strictly focus on COVID-19 MVC; and although it could be considered as a limit of our review, on the contrary, we believe that having also included other mass vaccination campaigns represents an added value to our work. Using this approach, we were as comprehensive as possible, taking other related experiences also into account. As mentioned, only one article on a COVID-19 mass vaccination center was identified. Moreover, a comprehensive description of an MVC planning could also have been limited by the under reporting of many practices that were so obvious, ubiquitous and/or routinely implemented that they were not uniformly and consistently reported. Some examples were the use of MVC signage and educational materials translated into multiple languages reported in just four articles $[49,56,57,59]$, and the conduction of promotional educational campaign aimed at the desired or target population for vaccination that was reported in just three articles. Actually, educational campaigns that are coordinated with public health officials and that include trust brokers are core public health and immunization best practices to widely publicize a mass vaccine clinic before implementation. Thus, even if some aspects are described in only a few articles, it is not possible to conclude that they have not been taken into account for the organization of other MVCs, rather than they have simply often not been reported. Among limitations, we should address the English limitation applied. However, because no articles were removed because of this language limitation, we are confident that our results are not affected by selection bias. Nevertheless, four articles were excluded because we were not able to retrieve the full text [18-21]. Specifically, the first was published in 1985; the second was a conference paper; the third also lacked an abstract, so it was not possible to make any assessment of the content; the last one evaluated similarities and differences in access and acceptance between vaccinations carried out in an MVC and those in a clinic (information extracted from the abstract). Taking into account all these considerations, we are confident that these exclusions did not bias our results.

Another significant limitation is represented by the substantial lack of evidences from Western countries other than the USA. This is particularly frustrating because some of the most successful mass campaigns against SARS-CoV-2 were performed in Israel and in high-income countries from Western Europe. In fact, such countries are only limitedly comparable to the USA, not only for the demographics (for example: in European Union, age group 65 years or older encompasses around $20.5 \%$ of the total population, compared to $16.2 \%$ in the USA) but also in terms of urban planning, with obvious consequences on the availability of adequate and accessible facilities to be converted in MVCs.

Lastly, to this day, the literature concerning this topic is still relatively sparse, allowing us only to draw preliminary conclusions. Moreover, the data mainly referred to simulation and single-day experiences that do not allow us to assess the long-term performance and impact of these mass vaccination centers. Nevertheless, to the best of our knowledge, this is the first review assessing the organization, implementation and performance of mass vaccination centers. In our view, this is an extremely relevant topic both for public health experts and policymakers involved in facing the challenges and threats posed by an infectious pandemic unprecedented in recent human history.

\section{Conclusions}

MVCs are usually acknowledged as the best solution to administer vaccines in the shortest time to the greatest number of people. Our results highlighted an important gap in knowledge because only a very small number of articles was retrieved on the topic. Moreover, these few available articles often under-reported many aspects of MVC organization. The current review answers to the urgency of organizing an MVC during the COVID-19 pandemic, highlighting the most important organizational aspects that should be considered in the planning. Among the others, the most important are the following: the identification of the site; the layout of the center; the identification of the number, role and type of the staff members; the training of the staff; the necessary equipment and 
vaccines transportation, cold-chain maintenance and storage. However, it should be kept in mind that organizational models might be context-specific based on structural needs or professional availability. Future researches should help better identify the necessary strategies in order to obtain an optimal vaccination rate across the mass vaccination centers, especially on the COVID-19 vaccination.

Supplementary Materials: The following are available online at https:/ /www.mdpi.com/article/10 .3390/vaccines9060574/s1, Table S1: Search strategy developed in each database; Table S2: Articles assessed in full and excluded with reasons.

Author Contributions: V.G., A.O. and C.S. conceptualized the study; V.G. designed the study and performed the literature search. V.G., A.L., G.E.R., M.M., and F.P. performed investigation and data curation. V.G. wrote the first draft. M.R. first review and editing. Subsequent validation, review and editing performed by all authors. C.S supervised the work. All authors have read and agreed to the published version of the manuscript.

Funding: This research received no external funding.

Institutional Review Board Statement: It was a systematic review; ethical approval was not required.

Informed Consent Statement: Not applicable.

Data Availability Statement: All data are presented in the current manuscript (text, tables, and Supplementary Materials).

Conflicts of Interest: The authors declare no conflict of interest.

\section{References}

1. Signorelli, C.; Odone, A.; Gianfredi, V.; Bossi, E.; Bucci, D.; Oradini-Alacreu, A.; Frascella, B.; Capravo, M.; Chiappa, F.; Blandi, L.; et al. The spread of COVID-19 in six western metropolitan regions: A false myth on the excess of mortality in Lombardy and the defense of the city of Milan. Acta Biomed. 2020, 91, 23-30. [CrossRef] [PubMed]

2. Signorelli, C.; Odone, A.; Gianfredi, V.; Bossi, E.; Bucci, D.; Oradini-Alacreu, A.; Frascella, B.; Capraro, M.; Chiappa, F; Blandi, L.; et al. COVID-19 mortality rate in nine high-income metropolitan regions. Acta Biomed. 2020, 91, 7-18. [PubMed]

3. Paciullo, F.; Giannandrea, D.; Gianfredi, V.; Borgognoni, F.; Verdecchia, P.; L'Angiocola, P.D.; Monti, M. Epidemiology of emergency calls for time-dependent acute illnesses during COVID-19 outbreak in Umbria region (Italy). Ann Ig. 2020, 33, 198-200. [PubMed]

4. Odone, A.; Delmonte, D.; Scognamiglio, T.; Signorelli, C. COVID-19 deaths in Lombardy, Italy: Data in context. Lancet Public Health 2020, 5, e310. [CrossRef]

5. World Health Organization. WHO Director-General's Opening Remarks at the Media Briefing on COVID-19 11 March World Health Organization, Geneve. 2020. Available online: https://www.who.int/director-general/speeches/detail/who-directorgeneral-s-opening-remarks-at-the-media-briefing-on-covid-19---11-march-2020 (accessed on 6 April 2021).

6. Bull, S.; Jamrozik, E.; Binik, A.; Parker, M.J. SARS-CoV-2 challenge studies: Ethics and risk minimisation. J. Med. Ethic 2020. [CrossRef]

7. Signorelli, C.; Scognamiglio, T.; Odone, A. COVID-19 in Italy: Impact of containment measures and prevalence estimates of infection in the general population. Acta Biomed. 2020, 91, 175-179.

8. Chung, J.Y.; Thone, M.N.; Kwon, Y.J. COVID-19 vaccines: The status and perspectives in delivery points of view. Adv. Drug Deliv. Rev. 2021, 170, 1-25. [CrossRef]

9. World Health Organization. Special Feature: Immunization and COVID-19. Second Pulse Poll Offers a more Detailed Understanding of Disruptions to Vaccination Caused by COVID-19 and How to Respond; World Health Organization: Geneve, Switzerland, 2021. Available online: https://www.who.int/immunization/monitoring_surveillance/immunization-and-covid-19/en/ (accessed on 11 April 2021).

10. Fontanet, A.; Cauchemez, S. COVID-19 herd immunity: Where are we? Nat. Rev. Immunol. 2020, 20, 583-584. [CrossRef]

11. Centers for Disease Control and Prevention. Guidelines for Large Scale Novel H1N1 Influenza Vaccination Clinics. 2009. Available online: https://www.cdc.gov/h1n1flu/vaccination/pdf/D_Wortley_H1N1_guidelines_pandemic.pdf (accessed on 8 April 2021).

12. Direction Générale de Santé Publique. Organisation des Centres de Vaccination de Masse Contre La COVID-19; Direction Générale de Santé Publique: Quebec, QC, Canada, 2021. Available online: https://ciusssmcq.ca/Content/Client/Librairie/Documents/COVID19/Vaccination_COVID_employes/Organisation-centre-vaccination-de-masse-12mars2021.pdf (accessed on 28 May 2021).

13. France24. Disneyland Paris to Host Mass Covid Vaccination Site. 2021. Available online: https://www.france24.com/en/livenews /20210421-disneyland-paris-to-host-mass-covid-vaccination-site (accessed on 26 May 2021). 
14. Azienda Unità Sanitaria Locale di Parma. Vaccinazioni Anti-Covid 19: Bollettino del 26/05/2021. Available online: https://www. ausl.pr.it/comunicazione_stampa/archivio_3/vaccinazioni_anti_covid_bollettino_2021_37.aspx (accessed on 26 May 2021).

15. Signorelli, C.; Odone, A.; Gianfredi, V.; Capraro, C.; Kacerik, E.; Chiecca, G.; Scardoni, A.; Minerva, M.; Mantecca, R.; Musarò, P.; et al. Application of the "immunization islands" model to improve quality, efficiency and safety of a COVID-19 mass vaccination site. Ann Ig. 2021, 5. [CrossRef]

16. Tricco, A.C.; Langlois, E.V.; Straus, S.E. Rapid Reviews to Strengthen Health Policy and Systems: A Practical Guide; World Health Organization: Geneva, Switzerland, 2017.

17. Moher, D.; Shamseer, L.; Clarke, M.; Ghersi, D.; Liberati, A.; Petticrew, M.; Shekelle, P.; Stewart, L.A.; PRISMA-P Group. Preferred reporting items for systematic review and meta-analysis protocols (PRISMA-P) 2015 statement. Syst. Rev. 2015, 4, 1. [CrossRef]

18. Fontanesi, J.; Hill, L.; Olson, R.; Bennett, N.M.; Kopald, D. Mass vaccination clinics versus appointments. J. Med. Pract. Manag. 2006, 21, 288-294.

19. Nolan, P. The Rhode Island meningitis vaccine experience-Mass vaccination campaigns, politics and health policy. Med. Health Rhode Isl. 2004, 87, 65-67.

20. Jarrett, S.W. Smallpox eradication: Selected management issues. Assign. Child. 1985, 72, 243-261.

21. Schindler, J.V.; Mraz, T. Agent-based modeling for real-time decision-support for point-of-distribution managers during influenza mass vaccination. AMIA Annu. Symp. Proc. 2008, 2008, 1124.

22. Dervaux, B.; Leleu, H.; Valdmanis, V.; Walker, D. Parameters of control when facing stochastic demand: A DEA approach applied to Bangladeshi vaccination sites. Int. J. Health Care Financ. Econ. 2003, 3, 287-299. [CrossRef]

23. Goralnick, E.; Kaufmann, C.; Gawande, A.A. Mass-Vaccination Sites-An Essential Innovation to Curb the Covid-19 Pandemic. N. Engl. J. Med. 2021, 384, e67. [CrossRef]

24. Ha, E.C.; McCoy, M.D.A.; Taylor, C.B.; Kirk, K.D.; Fry, C.R.S.; Modi, J.R. Using Lean Six Sigma Methodology to Improve a Mass Immunizations Process at the United States Naval Academy. Mil. Med. 2016, 181, 582-588. [CrossRef] [PubMed]

25. Iacobucci, G. Covid vaccine: GPs need more clarity on logistics and planning, say leaders. BMJ 2020, 371, m4555. [CrossRef] [PubMed]

26. Olmsted, S.S.; Grabenstein, J.D.; Jain, A.K.; Lurie, N. Patient experience with, and use of, an electronic monitoring system to assess vaccination responses. Health Expect. 2006, 9, 110-117. [CrossRef] [PubMed]

27. Savitz, S.; Stewart, J. Lessons Learned from Smallpox Vaccination of U.S. Navy Forces before Operation Iraqi Freedom. Mil. Med. 2007, 172, 353-358. [CrossRef] [PubMed]

28. Sim, F. Early Covid-19 vaccination rollout: A commentary from England. Isr. J. Health Policy Res. 2021, 10, 1-4. [CrossRef] [PubMed]

29. Sutter, R.W.; Maher, C. Mass vaccination campaigns for polio eradication: An essential strategy for success. Curr. Top. Microbiol. Immunol. 2006, 304, 195-220. [CrossRef]

30. Szilagyi, P.G.; Iwane, M.K.; Humiston, S.E.; Schaffer, S.; McInerny, T.; Shone, L.; Jennings, J.; Washington, M.L.; Schwartz, B. Time Spent by Primary Care Practices on Pediatric Influenza Vaccination Visits. Arch. Pediatrics Adolesc. Med. 2003, 157, 191-195. [CrossRef]

31. Kuehnert, P. Now More than Ever: Building and Sustaining Capacity for School-Located Vaccination Initiatives. J. Sch. Nurs. 2010, 26, 27S-29S. [CrossRef]

32. Lee, T.H.; Chen, A.H. Last-Mile Logistics of Covid Vaccination-The Role of Health Care Organizations. N. Engl. J. Med. 2021, 384, 685-687. [CrossRef] [PubMed]

33. Meyer, D.; Shearer, M.P.; Chih, Y.-C.; Hsu, Y.-C.; Lin, Y.-C.; Nuzzo, J.B. Taiwan's Annual Seasonal Influenza Mass Vaccination Program-Lessons for Pandemic Planning. Am. J. Public Health 2018, 108, S188-S193. [CrossRef]

34. Velimirovic, B. Mass vaccination programs administrative provisions and possibilities. La Ric. Clin. Lab. 1981, 2, 73-80.

35. Gerber, R.; Murtagh, L.; Wolbert, C.J.; Tinkey, N.M.; Gobeille, B. Recent Developments in Health Law. J. Law Med. Ethic 2007, 35, 495-506. [CrossRef] [PubMed]

36. Giot, J.L.; Loneux, J.C.; Mardaga, J.; Surleraux, C. Vaccination for viral hepatitis in industrial health. Acta Gastro Enterol. Belg. 2003, 66, 241-246.

37. Arthur, B.C.; Fisher, A.K.; Shoemaker, S.J.; Pozniak, A.; Stokley, S. Business Models, Vaccination Services, and Public Health Relationships of Retail Clinics: A Qualitative Study. J. Health 2015, 60, 429-440. [CrossRef]

38. Cho, B.-H.; Hicks, K.A.; Honeycutt, A.A.; Hupert, N.; Khavjou, O.; Messonnier, M.; Washington, M.L. A Tool for the Economic Analysis of Mass Prophylaxis Operations with an Application to H1N1 Influenza Vaccination Clinics. J. Public Health Manag. Pr. 2011, 17, E22-E28. [CrossRef] [PubMed]

39. Garske, T.; Van Kerkhove, M.D.; Yactayo, S.; Ronveaux, O.; Lewis, R.F.; Staples, J.E.; Perea, W.; Ferguson, N.M. For the Yellow Fever Expert Committee Yellow Fever in Africa: Estimating the Burden of Disease and Impact of Mass Vaccination from Outbreak and Serological Data. PLoS Med. 2014, 11, e1001638. [CrossRef]

40. Porco, T.C.; Holbrook, K.E.; Fernyak, S.; Portnoy, D.L.; Reiter, R.; Aragón, T.J. Logistics of community smallpox control through contact tracing and ring vaccination: A stochastic network model. BMC Public Health 2004, 4, 34. [CrossRef]

41. Matteson, L.M. Using Seasonal Influenza Clinics for Public Health Preparedness Exercises. AJN Am. J. Nurs. 2006, 106, 28-29. [CrossRef] 
42. Nicoll, A. Pandemic Risk Prevention in European Countries: Role of the ECDC in Preparing for Pandemics; Springer: Berlin/Heidelberg, Germany, 2010; pp. 1267-1276. [CrossRef]

43. Rambhia, K.J.K.J.; Watson, M.; Sell, T.K.; Waldhorn, R.; Toner, E. Mass Vaccination for the 2009 H1N1 Pandemic: Approaches, Challenges, and Recommendations. Biosecur. Bioterror. Biodef. Strategy Pract. Sci. 2010, 8, 321-330. [CrossRef]

44. Rebmann, T.; Loux, T.M.; Zink, T.K.; Swick, Z.; Wakefield, M. Infection prevention and mass vaccination training for U.S. point of dispensing staff and volunteers: A national study. Am. J. Infect. Control 2015, 43, 222-227. [CrossRef]

45. Rebmann, T.; Loux, T.M.T.M.; Swick, Z.; Dolgin, H.; Reddick, D.; Wakefield, M. Are US Jurisdictions Prepared to Dispense Medical Countermeasures Through Open Points of Dispensing? Findings from a National Study. Health Secur. 2015, 13, 96-105. [CrossRef] [PubMed]

46. Privor-Dumm, L.; Vasudevan, P.; Kobayashi, K.; Gupta, J. Archetype analysis of older adult immunization decision-making and implementation in 34 countries. Vaccine 2020, 38, 4170-4182. [CrossRef] [PubMed]

47. Sarma, H.; Budden, A.; Luies, S.K.; Lim, S.S.; Shamsuzzaman, M.; Sultana, T.; Rajaratnam, J.K.; Craw, L.; Banwell, C.; Ali, W.; et al. Implementation of the World's largest measles-rubella mass vaccination campaign in Bangladesh: A process evaluation. BMC Public Health 2019, 19, 1-10. [CrossRef]

48. Schwartz, B.; Wortley, P. Mass vaccination for annual and pandemic influenza. In Current Topics in Microbiology and Immunology; Springer: Berlin/Heidelberg, Germany, 2006; pp. 131-152.

49. Aaby, K.; Herrmann, J.W.; Jordan, C.; Treadwell, M.; Wood, K. Improving Mass Vaccination Clinic Operations. In Proceedings of the International Conference on Health Sciences Simulation, New Orleans, LA, USA, 23-27 January 2005.

50. Andress, K. A postevent smallpox mass vaccination clinic exercise. Disaster Manag. Response 2003, 1, 54-58. [CrossRef]

51. Asllani, A.; Dileepan, P.; Ettkin, L. A methodology for using simulation to optimize emergency mass vaccination parameters. $J$. Med. Syst. 2007, 31, 453-459. [CrossRef] [PubMed]

52. Asllani, A.; Dileepan, P.; Ettkin, L. Developing an Emergency Preparedness Plan: A Case for Simulation. Acad. Health Care Manag. J. 2007, 3, 51-63.

53. Caum, J.; Alles, S. Ready or Not: Analysis of a No-Notice Mass Vaccination Field Response in Philadelphia. Biosecurity Bioterrorism: Biodefense Strat. Pract. Sci. 2013, 11, 262-270. [CrossRef]

54. Gupta, A.; Evans, G.W.; Heragu, S.S. Simulation and optimization modeling for drive-through mass vaccination-A generalized approach. Simul. Model. Pract. Theory 2013, 37, 99-106. [CrossRef]

55. Ha, C.; Taylor, C.; Modi, J.R. Mass Vaccinations at the United States Naval Academy. Health Secur. 2016, 14, 382-388. [CrossRef] [PubMed]

56. Jenlink, C.H.; Kuehnert, P.; Mazyck, D. Key Components of a School-Located Vaccination Clinic: Lessons Learned from Fall 2009. J. Sch. Nurs. 2010, 26, 14S-26S. [CrossRef] [PubMed]

57. Jenlink, C.H.; Kuehnert, P.; Mazyck, D. Influenza Vaccinations, Fall 2009: Model School-Located Vaccination Clinics. J. Sch. Nurs. 2010, 26, 7S-13S. [CrossRef] [PubMed]

58. Kar, S.K.; Sah, B.; Patnaik, B.; Kim, Y.H.; Kerketta, A.S.; Shin, S.; Rath, S.B.; Ali, M.; Mogasale, V.; Khuntia, H.K.; et al. Mass Vaccination with a New, Less Expensive Oral Cholera Vaccine Using Public Health Infrastructure in India: The Odisha Model. PLoS Negl. Trop. Dis. 2014, 8, e2629. [CrossRef] [PubMed]

59. Phillips, F.B.; Williamson, J.P. Local Health Department Applies Incident Management System for Successful Mass Influenza Clinics. J. Public Health Manag. Pract. 2005, 11, 269-273. [CrossRef]

60. Porter, D.; Hall, M.; Hartl, B.; Raevsky, C.; Peacock, R.; Kraker, D.; Walls, S.; Brink, G. Local Health Department 2009 H1N1 Influenza Vaccination Clinics-CDC Staffing Model Comparison and Other Best Practices. J. Public Health Manag. Pract. 2011, 17, 530-533. [CrossRef]

61. Swift, M.D.; Aliyu, M.H.; Byrne, D.W.; Qian, K.; McGown, P.; Kinman, P.O.; Hanson, K.L.; Culpepper, D.; Cooley, T.J.; Yarbrough, M.I. Emergency Preparedness in the Workplace: The Flulapalooza Model for Mass Vaccination. Am. J. Public Health 2017, 107, S168-S176. [CrossRef]

62. COVID-19 Vaccines Begin at Disneyland Parking Lot, Orange County's First Super Site. Available online: https://www.ocregister com/2021/01/13/covid-19-vaccine-shots-begin-at-disneyland-parking-lot-orange-countys-first-super-site/ (accessed on 27 May 2021).

63. Yang, J.; Acosta, C.J.; Si, G.-A.; Zeng, J.; Li, C.-Y.; Liang, D.-B.; Ochiai, R.L.; Page, A.-L.; Danovaro-Holliday, M.C.; Zhang, J.; et al. A mass vaccination campaign targeting adults and children to prevent typhoid fever in Hechi; Expanding the use of Vi polysaccharide vaccine in Southeast China: A cluster-randomized trial. BMC Public Health 2005, 5, 49. [CrossRef]

64. Bundesanstalt für Arbeitsschutz und Arbeitsmedizin. Empfehlung des Ausschusses für Biologische Arbeitsstoffe (ABAS) zu "Arbeitsschutzmaßnahmen bei der Durchführung von Impfungen gegen SARS-CoV-2 in Impfzentren". Berlin; January 2021 Contract No.: Beschluss 21/2020. Available online: https://www.baua.de/DE/Aufgaben/Geschaeftsfuehrung-vonAusschuessen/ABAS/Empfehlungen.html (accessed on 27 May 2021).

65. National Health Service. COVID-19 Vaccination Centres: Operating Framework. Information and Guidance on Operating Vaccination Centres. 20 January 2021 Contract No.: 001559. Available online: https://www.england.nhs.uk/coronavirus/ wp-content/uploads/sites/52/2021/01/C1034-operating-framework-information-and-guidance-on-operating-vaccinationcentres-v1.1-20-january-21.pdf (accessed on 27 May 2021). 
66. Gianfredi, V.; Dallagiacoma, G.; Provenzano, S.; Santangelo, O.E. Factors predicting health science students' willingness to be vaccinated against seasonal flu during the next campaign. Ann Ist Super Sanita 2019, 55, 209-216. [PubMed]

67. Riccò, M.; Vezzosi, L.; Gualerzi, G.; Signorelli, C. Knowledge, attitudes and practices (KAP) towards vaccinations in the school settings: An explorative survey. J. Prev. Med. Hyg. 2017, 58, E266-E278. [PubMed]

68. Ricco, M.; Vezzosi, L.; Gualerzi, G.; Balzarini, F.; Mezzoiuso, A.G.; Odone, A.; Signorelli, C. Measles vaccine in the school settings: A cross-sectional study about knowledge, personal beliefs, attitudes and practices of school teachers in northern Italy. Minerva Pediatrica 2018. [CrossRef]

69. Wallace, M.; Woodworth, K.R.; Gargano, J.W.; Scobie, H.M.; Blain, A.E.; Moulia, D.; Chamberland, M.; Reisman, N.; Hadler, S.C.; MacNeil, J.R.; et al. The Advisory Committee on Immunization Practices' Interim Recommendation for Use of Pfizer-BioNTech COVID-19 Vaccine in Adolescents Aged 12-15 Years-United States, May 2021. MMWR. Morb. Mortal. Wkly. Rep. 2021, 70, 749-752. [CrossRef]

70. Ricco, M.; De Nard, F.; Peruzzi, S. Mosaic vaccination schedule: An unexpected card to play against SARS-CoV-2? Infect. Dis. Now 2021, 51, 402-405. [CrossRef]

71. Cella, P.; Voglino, G.; Barberis, I.; Alagna, E.; Alessandroni, C.; Cuda, A.; D'Aloisio, F.; Dallagiacoma, G.; De Nitto, S.; Di Gaspare, F.; et al. Resources for assessing parents' vaccine hesitancy: A systematic review of the literature. J Prev. Med. Hyg. 2020, 61, E340-E373.

72. Gianfredi, V.; Grisci, C.; Nucci, D.; Parisi, V.; Moretti, M. Communication in health. Recenti Prog Med. 2018, 109, 374-383. [CrossRef]

73. Razai, M.S.; Chaudhry, U.A.R.; Doerholt, K.; Bauld, L.; Majeed, A. Covid-19 vaccination hesitancy. BMJ 2021, 373. [CrossRef]

74. Bass, S.B.; Wilson-Genderson, M.; Garcia, D.T.; Akinkugbe, A.A.; Mosavel, M. SARS-CoV-2 Vaccine Hesitancy in a Sample of US Adults: Role of Perceived Satisfaction with Health, Access to Healthcare, and Attention to COVID-19 News. Front. Public Health 2021, 9, 665724. [CrossRef] [PubMed]

75. Coustasse, A.; Kimble, C.; Maxik, K. COVID-19 and Vaccine Hesitancy. J. Ambul. Care Manag. 2021, 44, 71-75. [CrossRef] [PubMed]

76. Odone, A.; Bucci, D.; Croci, R.; Riccò, M.; Affanni, P.; Signorelli, C. Vaccine hesitancy in COVID-19 times. An update from Italy before flu season starts. Acta Biomed. 2020, 91, e2020031.

77. Gianfredi, V.; Monarca, S.; Moretti, M.; Villarini, M. Health education, what is the role for pharmacist? Results from a cross sectional study in Umbria, Italy. Recenti Progress. Med. 2017, 108, 433-441.

78. Gianfredi, V.; Odone, A.; Fiacchini, D.; Rosselu, R.; Battista, T.; Signorelli, C. Trust and reputation management, branding, social media management nelle organizzazioni sanitarie: Sfide e opportunity per la comunita igienistica italiana. J. Prev. Med. Hyg. 2019, 60, E108-E109.

79. Government of Canada. Planning Guidance for Immunization Clinics for COVID-19 Vaccines. 2021. Available online: https:/ / www.canada.ca/en/public-health/services/diseases/2019-novel-coronavirus-infection/guidance-documents / planning-immunization-clinics-covid-19-vaccines.html\#a2.2 (accessed on 20 May 2021).

80. Gianfredi, V.; Moretti, M.; Lopalco, P.L. Countering vaccine hesitancy through immunization information systems, a narrative review. Hum. Vaccines Immunother. 2019, 15, 2508-2526. [CrossRef] [PubMed]

81. Gianfredi, V.; Balzarini, F.; Gola, M.; Mangano, S.; Carpagnano, L.F.; Colucci, M.E.; Gentile, L.; Piscitelli, A.; Quattrone, F.; Scuri, S.; et al. Leadership in Public Health: Opportunities for Young Generations Within Scientific Associations and the Experience of the "Academy of Young Leaders". Front. Public Health 2019, 7, 378. [CrossRef] 